\title{
Influence of Long-Term Impact of Elevated Temperature on the Physical Properties of the Sanicro 25 Steel
}

\author{
M. Sroka ${ }^{a * *}$, A. Zieliński ${ }^{b}$, G. Golański ${ }^{c}$, T. PuszczaŁo $^{d}$ And J. ZaCŁona ${ }^{a}$ \\ ${ }^{a}$ Silesian University of Technology, Department of Engineering Materials and Biomaterials, \\ S. Konarskiego 18A, 44-100 Gliwice, Poland \\ ${ }^{b}$ Eukasiewicz Research Network Institute for Ferrous Metallurgy, \\ K. Miarki 12-14, 44-100 Gliwice, Poland \\ ${ }^{c}$ Częstochowa University of Technology, Institute of Materials Engineering, \\ al. Armii Krajowej 19, 42-200 Częstochowa, Poland \\ ${ }^{d}$ ZRE, Katowice, Poland
}

Doi: $10.12693 /$ APhysPolA.138.232

*e-mail: marek.sroka@polsl.pl

\begin{abstract}
The X7NiCrWCuCoNbNB25-23-3-3-2 (Sanicro 25) austenitic stainless steel is one of the newest and most promising steels for applications in ultra-supercritical and super-ultra-supercritical power units. In this work, the results of tests on microstructure changes and mechanical properties of Sanicro 25 steel after long-term ageing up to $20,000 \mathrm{~h}$ at $700{ }^{\circ} \mathrm{C}$ are presented. Investigation of the microstructure was performed using scanning electron microscopy and transmission electron microscopy. The identification of secondary phases was carried out by X-ray phase composition. Prolonged exposure to elevated temperature causes a change in strength properties due to the precipitation of secondary phases. The effect of ageing time at $700{ }^{\circ} \mathrm{C}$ on yield strength, tensile strength, and elongation determined at room temperature is shown.
\end{abstract}

topics: Sanicro 25, microstructure, mechanical properties, ageing

\section{Introduction}

In order to increase the efficiency of the existing power units and reduce the costs of electricity generation, the modernisation of units operated for a long time has been carried out in recent years in Poland. The major concern is $200 \mathrm{MW}$ units. In 2017, the number of such units operating in Poland was 54, representing approximately $50 \%$ of the total installed power in the commercial power generation sector. Most of them are more than 40 years old, and their service time has already exceeded 200,000 h, and in some cases even 300,000 h, a long time ago. Their efficiency is approximately $36 \%$, which is well below the average level in the EU (approximately 44\%). Therefore, they do not comply with the assumed technical and economic as well as environmental indicators [1-5].

The investments to upgrade the existing power units are not sufficient to meet the urgent energy needs and require to seek for new directions in development of the Polish electrical power engineering, such as those presented in the draft version of the Poland energy strategy until 2040. One of the proposed solutions is to increase the operating parameters of power units up to the supercritical values, i.e. approximately $28 \mathrm{MPa} / 600^{\circ} \mathrm{C} / 620^{\circ} \mathrm{C}$, which requires to use materials with increased functional properties [6-10].
The Sanicro 25 austenitic stainless steel is one of the newest and most promising steels for applications in ultra-supercritical and super-ultrasupercritical power units. This steel was produced under the European Therme AD700 program aimed at the development of a new type of power unit, and thereby the structural materials with a stable microstructure, high strength properties and significant resistance to corrosion and steam oxidation during service at $700^{\circ} \mathrm{C}$. The new material is assumed to enable the development of power units with an efficiency of around $50 \%$ [11].

\section{Material and experimental methods}

The investigations were carried out on the test specimen of $\varphi 38 \times 8.8 \mathrm{~mm}^{2}$ taken from a superheater coil made of X7NiCrWCuCoNbNB25-23-33-3-2 creep-resistant austenitic steel, acquired during the project for selection of materials for modern power engineering.

High corrosion and oxidation resistance of Sanicro 25 steel in steam atmosphere at up to $700{ }^{\circ} \mathrm{C}$ is provided by chromium content of $21.5-23.5 \mathrm{wt} \%$ (Table I). The corrosion and oxidation resistance of the test steel is also affected to a significant extent by its fine-grained structure. According to [12], the resistance to oxidation of creep-resistant austenitic 
TABLE I

The chemical composition (in wt\%) of the test material with reference to the requirements of Vd TUV555 09.2008

\begin{tabular}{c|c|c|c}
\hline \hline $\mathrm{C}$ & $\mathrm{Si}$ & $\mathrm{Mn}$ & $\mathrm{P}$ \\
\hline $0.04 \div 0.11$ & $\max .0 .40$ & $\max .0 .60$ & $\max .0 .025$ \\
\hline $\mathrm{S}$ & $\mathrm{Cr}$ & $\mathrm{W}$ & $\mathrm{Ni}$ \\
\hline $\max .0 .015$ & $2.0 \div 3.5$ & $21.5 \div 23.5$ & $23.5 \div 26.5$ \\
\hline $\mathrm{Co}$ & $\mathrm{Cu}$ & $\mathrm{Nb}$ & $\mathrm{B}$ \\
\hline $2.0 \div 4.0$ & $1.0 \div 2.0$ & $0.30 \div 0.60$ & $\max .0 .008$
\end{tabular}

steels is improved by grain size of at least 7 according to the scale of standards, since the grain boundaries create favourable conditions for chromium diffusion.

The stability of unbalanced austenitic structure is provided not only by high content of nickel (23.5-26.6 wt\%), but also of nitrogen (0.15-0.30 wt\%). The heat treatment of Sanicro 25 steel consists of solutioning at $1180-1250^{\circ} \mathrm{C}$ and water or air cooling.

The observation of microstructure of Sanicro 25 steel was performed with a light microscope and scanning electron microscope on conventionally prepared electrolytically etched metallographic microsections. The identification of precipitates in Sanicro 25 steel was carried out with FEI S/TEM TITAN 80-300 high-resolution electron microscope. The phase identification of precipitates was performed with thin foils by the selective electron diffraction method. The investigations of strength properties were carried out as part of the static tensile test on plane specimens. The research was carried out on material in the as-received condition and after long-term ageing at $700{ }^{\circ} \mathrm{C}$ for $20,000 \mathrm{~h}$.

\section{Results and discussions}

In the as-received condition, Sanicro 25 steel was characterised by approximately $14 \%$ higher tensile strength $R_{m}$ and approximately $25 \%$ higher yield strength $R_{p 0.2}$ compared to the required mechanical properties. Elongation was at the required minimum level [13].

Prolonged exposure to high temperatures resulted in a change in mechanical properties due to the precipitation of secondary phases, gradual change in their chemical composition, spheroidisation and coagulation processes and depletion of matrix by alloying elements as a result of their diffusion to the occurring precipitates $[11,14]$. During the initial ageing period, fine precipitates significantly increase the strength properties (yield strength and tensile strength) while reducing the elongation.

Figure 1 shows the effect of ageing time at $700^{\circ} \mathrm{C}$ on tensile strength $R_{m}$, yield strength $R_{p 0.2}$ (Fig. 2) and elongation A (Fig. 3) determined at room temperature of Sanicro 25 steel.

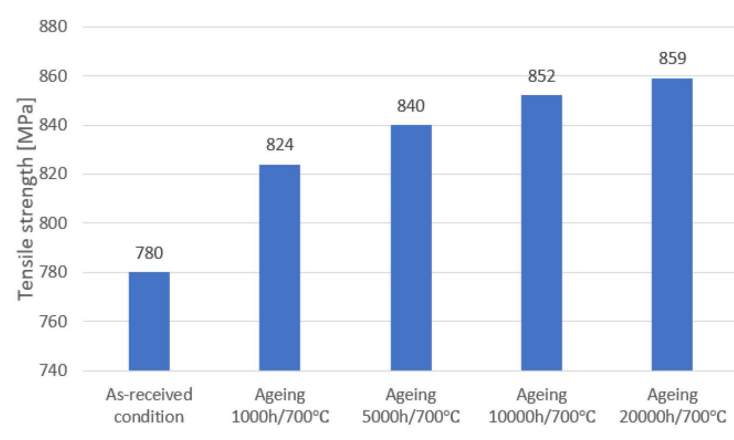

Fig. 1. Change in tensile strength of Sanicro 25 steel after long-term ageing at $700{ }^{\circ} \mathrm{C}$.

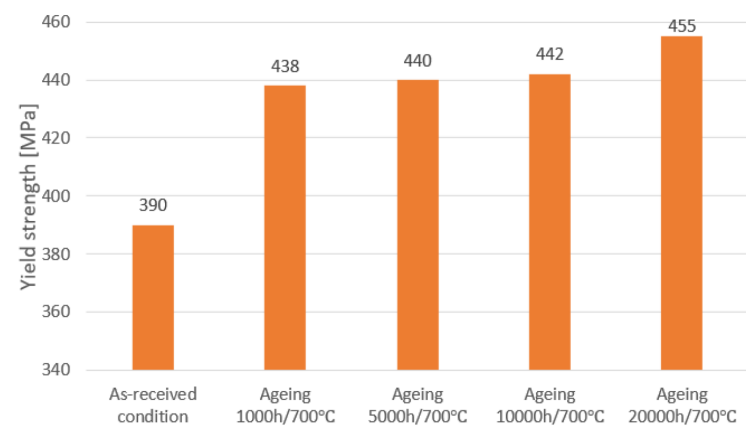

Fig. 2. As in Fig. 1, but for change in yield strength. at $700^{\circ} \mathrm{C}$.

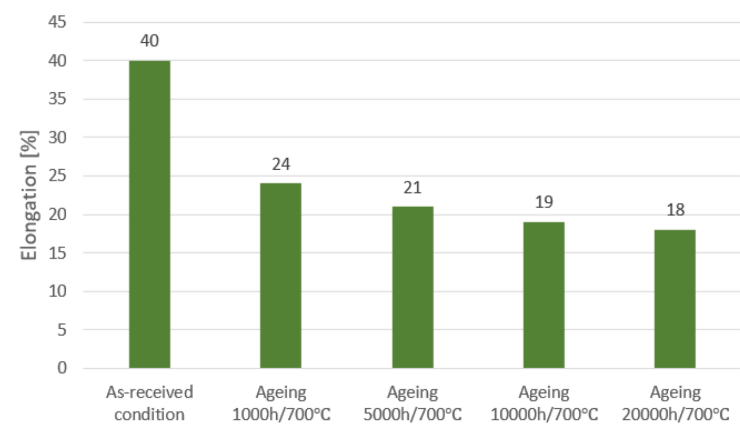

Fig. 3. As in Fig. 1, but for change in elongation.

A slight increase in tensile strength is observed until the ageing time of $20,000 \mathrm{~h}$ when it amounted to $10 \%$ relative to the as-received condition of the material. For yield strength, also a slight increase (approximately 17\%) in relation to the as-received condition is visible, whereas extension, after ageing for up to $20,000 \mathrm{~h}$, halved compared to elongation of the material in the as-received condition.

In the microstructure of the test steel in the solution-treated condition, primary $\mathrm{NbX}$ and $\mathrm{NbCrN}$ precipitates ( $Z$ phase) occur (Fig. 4 ). These particles are precipitated at the final stage of crystallisation, therefore most of them are observed near or at the grain boundaries. Due to their micrometric dimensions, the primary precipitates do not play a significant role in hardening of the test steel. 


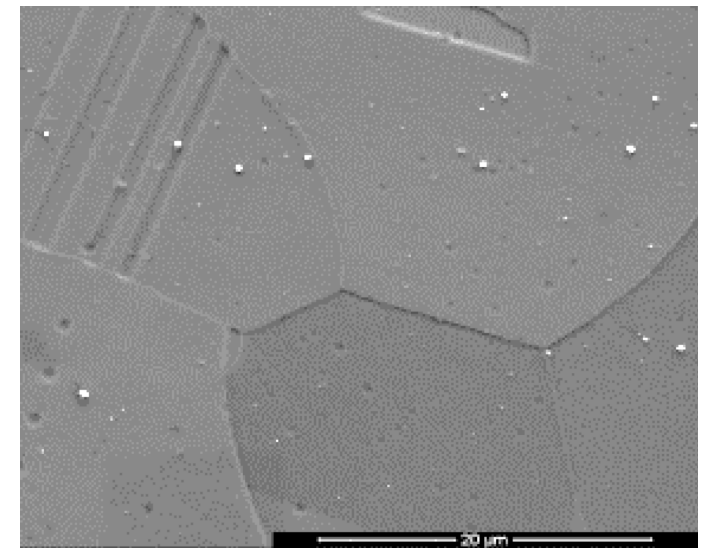

Fig. 4. Microstructure of Sanicro 25 in the asreceived condition, scanning electron microscopy (SEM).
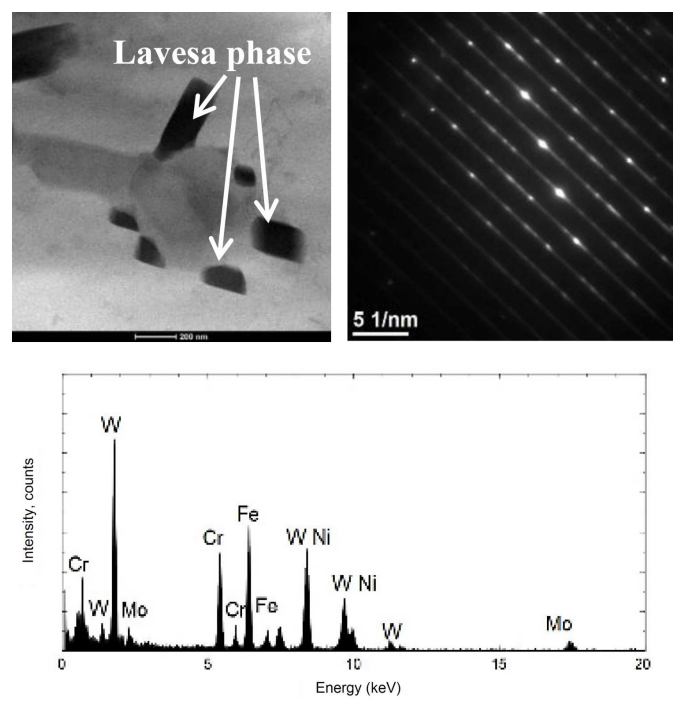

Fig. 5. Laves phase in Sanicro 25 steel after $1,000 \mathrm{~h}$ ageing at $750^{\circ} \mathrm{C}$.

Ageing of Sanicro 25 steel contributes to the precipitation of secondary phases (Fig. 5) both at and inside the austenite grain boundaries, and the sequence of occurring precipitates and changes in their size depends on ageing temperature and time. Numerous fine precipitates occur both randomly and systematically in the matrix and are visible inside the grains. Fine-dispersion precipitates inside the grains have a favourable impact on properties by inhibiting dislocation movements, but this effect depends on the stability of the given type of precipitate. Coagulation of particles precipitated inside the grains impairs this impact [15].

After long-term ageing, mainly two types of precipitates were observed at the grain boundaries: $\mathrm{M}_{23} \mathrm{C}_{6}$ and $\sigma$ phase. Their size, shape and amount changes as the ageing time increases, and this process shows a definitely higher dynamics than the changes in precipitation processes inside the grains $[16,17]$.

\section{Conclusions}

The investigations of the microstructure of Sanicro 25 steel after long-term ageing of up to $20,000 \mathrm{~h}$ at $700{ }^{\circ} \mathrm{C}$ made it possible to evaluate the dynamics of changes in the microstructure and the intensive precipitation process.

The increase in tensile strength and yield strength at the expense of plastic properties was observed.

On the basis of the investigations performed, mechanical and plastic properties, phase composition and analysis of changes in the microstructure of the test steel, the Sanicro 25 steel can be concluded to be suitable for use in the power industry for the construction of ultra-supercritical boilers.

\section{Acknowledgments}

This publication was co-financed within the framework of the statutory financial grant supported by the Faculty of Mechanical Engineering of the Silesian University of Technology.

\section{References}

[1] M. Sroka, A. Zieliński, J. Mikuła, Arch. Metall. Mater. 61, 969 (2016).

[2] T. Tański, P. Snopinski, W. Borek, Mater. Manuf. Process. 32, 1368 (2017).

[3] L.W. Żukowska, A. Śliwa, J. Mikuła, M. Bonek, W. Kwaśny, M. Sroka, D. Pakuła, Arch. Metall. Mater. 61, 149 (2016).

[4] A. Śliwa, W. Kwaśny, M. Sroka, R. Dziwis, Metalurgija 56, 422 (2017).

[5] G. Golaśki, A. Zielińska-Lipiec, A. Zieliński, M. Sroka, J. Mater. Eng. Perform. 26, 1101 (2017).

[6] D. Pakuła, M. Staszuk, K. Gołombek, A. Śliwa, J. Mikuła, Arch. Metall. Mater. 61, 919 (2016).

[7] A. Śliwa, M. Bonek, Metalurgia 65, 223 (2017).

[8] W. Borek, T. Tanski, Z. Jonsta, P. Jonsta, L. Cizek, in: Proc. METAL 2015: 24th Int. Conf. on Metallurgy and Materials, 2015, p. 307.

[9] P. Snopiński, M. Król, T. Tański, B. Krupińska, J. Therm. Anal. Calorim. 133, 379 (2018).

[10] M. Król, T. Tański, G. Matula, P. Snopiński, A.E. Tomiczek, Arch. Metall. Mater. 60, 2993 (2015).

[11] G. Chai, U. Forsberg, in: Materials for Ultra-Supercritical and Advanced UltraSupercritical Power Plants, Ed. A. Di Gianfrancesco, Woodhead Publ., 2017, p. 391. 
[12] R.L. Plaut, C. Herrera, D.M. Escriba, P.R. Rios, A.F. Padilha, Mater. Res. 10, 453 (2007).

[13] P. Nyblom, J. HĂśgberg, M. Herrdin, U. Forsberg, "Uns S31035 A New Austenitic Tube Grade For Use In Coal Fired Boilers At Material Temperatures Up To About $700^{\circ} \mathrm{C} " \mathrm{NACE}$ International, Atlanta (GA) 2009.

[14] M. Sroka, A. Zieliński, G. Golański, Acta Phys. Pol. A 135, 207 (2019).
[15] T. Sourmail, Mater. Sci. Techn. 14, 1 (2001).

[16] J.-Z. Wang, Z.-D. Liu, H.-S. Bao, S.-C. Cheng, B. Wang, J. Iron Steel Res. Int. 20, 54 (2013).

[17] J.W. Bai, P.P. Liu, Y.M. Zhu, C.Y. Chi, X.Y. Yu, X.S. Xie, Q. Zhan, Mater. Sci. Eng. A Struct. 584, 57 (2013). 